\title{
Effect of protein and prebiotic on the survival of encapsulated probiotic during storage
}

\author{
Patchanok Apiwattanasiri ${ }^{1}$, Ratchanee Charoen ${ }^{2}$, Kriangkrai Phattayakorn ${ }^{3}$, Sakwiboon Jantrasee ${ }^{4}$ and Wanticha \\ Savedboworn ${ }^{1 *}$ \\ ${ }^{1}$ Department of Agro-Industry Technology and Management, Faculty of Agro-Industry, King Mongkut's University of Technology \\ North Bangkok, Prachinburi, Thailand \\ ${ }^{2}$ Department of Innovation and Product Development Technology, Faculty of Agro-Industry, King Mongkut's University of Technology \\ North Bangkok, Prachinburi, Thailand \\ ${ }^{3}$ Department of Food Technology and Nutrition, Faculty of Natural Resources and Agro-Industry, Kasetsart University, Chalermphrakiat \\ Sakon Nakhon Province Campus, Sakon Nakhon, Thailand \\ ${ }^{4}$ Department of Applied Physics, Faculty of Engineering, Rajamangala University of Technology Isan, Khon Kaen Campus, Khon Kaen, \\ Thailand
}

\begin{abstract}
The aim of this research was to investigate the impact of encapsulation system on its protective capability during freeze drying of Lactobacillus casei TISTR 1463 and its storage at $4^{\circ} \mathrm{C}$ and $30^{\circ} \mathrm{C}$ for 90 and 60 days, respectively. Sericin extract is a kind of protein with gel-like property that could aid in binding and also contains important amino acids. The combinations of sericin and prebiotics, including isomaltooligosaccharide and modified starch were evaluated during microencapsulation of probiotic L. casei TISTR 1463 in alginate beads. The highest encapsulation efficiency was $97.61 \%$ with the addition of sericinisomalto-oligosaccharide. Encapsulated probiotic with sericin-modified starch had the lowest specific rate of degradation $(\mathrm{k})$ of $3.74 \times 10^{-2}$ day $^{-1}$ and $1.09 \times 10^{-1}$ day $^{-1}$ at both storage temperatures of $4{ }^{\circ} \mathrm{C}$ and $30^{\circ} \mathrm{C}$, respectively. Probiotic property of cell surface hydrophobicity (CSH) was also carried out.
\end{abstract}

Keyword. Encapsulation; sericin; probiotic; prebiotic.

\section{Introduction}

Currently, the consumers are more interested in personal health. Therefore, consuming foods that help promote or prevent various diseases and dietary supplements are on the rise [1]. Probiotics are the term for life and are defined as "Living microorganisms that positively affect the health of the host by balancing the microbial communities in intestine" [2]. Probiotic is a group of microorganisms that are beneficial to the human body and animals that can be found in the intestine called Gastrointestinal (GI) Tract. The survival of probiotic strain is a great significance to ensure a positive result on human health. Several reports have been found indicating low survivability of probiotic strain in products $[3,4]$. Therefore, the use of techniques or methods to maintain probiotic survival is becoming interest. Microencapsulation is the technology that is effective in helping to preserve and protect bacterial cells and it has been continuously generate to use in food industry [5]. Microencapsulation has been performed as an efficient way to protect probiotic cells from detriment in improper conditions before reaching the colon $[6,7,8]$. Prebiotics are food components that are not digestible in the stomach and small intestine but stimulate the development of beneficial bacteria in the gut. Good prebiotics should be able to withstand unchanged digestion of stomach acid and go down into the large intestine [9]. Sericin is a water-soluble protein obtained as a by-product in the silk industry. Sericin is very useful as biomaterial in tissue engineering, drug delivery and cell delivery [10]. This study aimed to determine the efficiency of alginate, sericin protein and prebiotics on the survival of encapsulated Lactobacillus casei TISTR 1463 during storage. Moreover, the probiotic properties of cell surface hydrophobicity was also evaluated.

\section{Material and methods destroyed}

\subsection{Bacterial culture}

Probiotic Lactobacillus casei TISTR 1463 was purchased from TISTR Culture collection, Thailand. Probiotic microorganism was subcultured twice in MRS broth (Merck, Darmstadt, Germany) and incubated at 37 ${ }^{\circ} \mathrm{C}$ for $36 \mathrm{~h}$. Probiotic culture was centrifuged at 4000 rpm for $10 \mathrm{~min}$. Cell pellets were washed with $0.85 \%$ $\mathrm{NaCl}$ and prepared for encapsulation.

\subsection{Freeze drying of encapsulated probiotic}

Encapsulated materials including alginate (Chemipan, Chemipan Corporation Co., Ltd., Thailand), sericin and each prebiotic consisted of modified starch (phyboplus;

\footnotetext{
* Corresponding author: wanticha.s@agro.kmutnb.ac.th
} 
SMS Corporation, Thailand) and isomaltooligosaccharide (Isomalt; Brenntag Ingredients, Thailand) were combined with L. casei TISTR 1463 at a ratio of $0.5 \%: 0.5 \%: 15 \%(\mathrm{w} / \mathrm{v})($ sericin : prebiotic : probiotics) or $1 \%: 15 \%(\mathrm{w} / \mathrm{v})$ (sericin : probiotics). Then, $60 \mathrm{~mL}$ of $2 \%(\mathrm{w} / \mathrm{v})$ sodium alginate were mixed with the suspension and then added to $18 \mathrm{G}$ syringe (Nipro Corporation, Belgium). The suspensions were dripped down into $0.2 \mathrm{M} \mathrm{CaCl}_{2}$ and mixed for $30 \mathrm{~min}$. Gel beads were washes with $0.85 \%(\mathrm{w} / \mathrm{v}) \mathrm{NaCl}$ and viable cell number were enumerated by drop plate technique. Encapsulated probiotics were applied to a plate freezer at $-44{ }^{\circ} \mathrm{C}$ for $24 \mathrm{hr}$. The freeze-drying process was carried out at $0.12 \mathrm{mbar},-50^{\circ} \mathrm{C}$ for $19 \mathrm{~h}$ with a freeze dryer (Alpha LSC1-4, Christ, Osterode amHarz, Germany). $0.5 \mathrm{~g}$ of freeze-dried encapsulated beads were packed into sealed polyethylene aluminum foil bags. The freezedried samples were kept at $4^{\circ} \mathrm{C}$ and $30^{\circ} \mathrm{C}$ for 90 days and 60 days, respectively. Each sample was analysed at the time interval to evaluate viable cell number.

\subsection{Encapsulation efficiency}

$1.0 \mathrm{~g}$ of fresh encapsulated probiotics were added to 9.0 $\mathrm{mL}$ of $2 \%$ sodium citrate at $\mathrm{pH} 8.3$ and vortex for 10 min. Ten-fold serial dilution with $0.85 \% \mathrm{NaCl}$ was evaluated. Drop plate technique was performed to investigate the viable cell number of probiotic. Encapsulation efficiency was measured as this equation:

Encapsulation efficiency $(\%)=\frac{x_{t}}{x_{0}} \times 100$

where $X_{t}$ is the number of viable probiotic released from the microparticles bacteria and $\mathrm{X}_{0}$ is the initial amount of bacteria [11].

\subsection{The stability of freeze-dried encapsulated probiotic}

$1.0 \mathrm{~g}$ of freeze-dried encapsulated probiotics were added to $9.0 \mathrm{~mL}$ of $2 \%$ sodium citrate at $\mathrm{pH} 8.3$ and vortex for 10 min. Ten-fold serial dilution with $0.85 \% \mathrm{NaCl}$ was evaluated. Drop plate technique was used to enumerate viable cell count on the MRS agar with the addition of $0.5 \% \mathrm{CaCO}_{3}$. Survival rate was calculated as the following equation:

Survival rate $(\%)=\frac{\mathrm{N}}{\mathrm{N}_{0}} \times 100$

where $\mathrm{N}$ is probiotic viability in term of $(\log \mathrm{CFU} / \mathrm{g})$ at a particular time and $\mathrm{N}_{0}$ defined as the initial viable cell in term of $(\log \mathrm{CFU} / \mathrm{g})$.

The specific rate of degradation $\left(k\right.$, day $\left.^{-1}\right)$ of dried encapsulated microparticles was investigated as a first order kinetic from the following equation:

$$
\log \frac{\mathrm{N}}{\mathrm{N}_{0}}=-k \cdot \mathrm{t}
$$

where $\mathrm{N}$ is the cell number at a particular time $(\mathrm{CFU} / \mathrm{g})$, $\mathrm{N}_{0}$ is the viable cell count at the initial time $(\mathrm{CFU} / \mathrm{g})$ and $\mathrm{t}$ is the storage time (days) [12].

\subsection{Cell surface hydrophobicity}

Cell surface hydrophobicity was evaluated as the methods of Savedboworn [13] with minor modifications. $1.0 \mathrm{~g}$ of freeze-dried encapsulated probiotics were released with $9 \mathrm{~mL}$ of $2 \%$ sodium citrate at $\mathrm{pH} 8.3$ and vortex for $10 \mathrm{~min}$. The solution was regulated to $\mathrm{OD}_{600}$ of 0.5 . Then, cell suspension $(3 \mathrm{~mL})$ was transferred to test tube and xylene $(1 \mathrm{~mL})$ (Ajax finechem, Australia) was applied. The mixture was mixed for $90 \mathrm{sec}$ and left to set for $15 \mathrm{~min}$ at room temperature. The bottom transparent of mixture was taken and analysed by a UVVis Spectrophotometer (Libra S22, Biochrom Ltd., UK) at $600 \mathrm{~nm}$ [12] and calculated as a percentage of cell surface hydrophobicity as this equation:

Cell surface hydrophobicity $=\left[1-\left(\frac{\mathrm{A}_{1}}{\mathrm{~A}_{0}}\right)\right] \times 100$

Where $A_{0}$ is the absorbance at $600 \mathrm{~nm}$ before and $A_{1}$ is the absorbance at $600 \mathrm{~nm}$ after mixing with xylene.

\subsection{Size measurement}

The 20 microcapsules of each treatment were measured using a vernier caliper to measure the diameter. The measuring unit in term of $\mathrm{mm}$. was expressed.

\subsection{Microcapsules morphology}

The structure of freeze-dried encapsulated cells was studied by a Scanning electron microscope (SEM) (Auriga, Zeiss, Germany). Dried encapsuled probiotic beads with gold plating were mounted on a double carbon tape on a stud. The images were observed and photographed at $3000 \mathrm{X}$ magnification.

\subsection{Statistical analysis}

The mean value and standard variation of at least triplicate were calculated. Data was analysed by SPSS statistical program version 26 . The analysis of variance (ANOVA) was performed at $95 \%$ confidence intervals. A significant difference among mean value was determined with DMRT.

\section{Results and discussion}

\subsection{Encapsulation efficiency of probiotics with various wall materials}

The number of probiotic encapsulated with alginate, sericin and different prebiotics including Phyboplus and Isomalt were determined. A significant difference $(p<0.05)$ in encapsulation efficiency after encapsulation was obtained. The encapsulation of $2 \%$ Sodium Alginate 
$+\quad 0.5 \%$ Sericin $+0.5 \%$ Isomalt had the highest encapsulation efficiency of $97.60 \%$ followed by $2 \%$ Sodium Alginate (control), $2 \%$ Sodium Alginate $+0.5 \%$ Sericin, 2\% Sodium Alginate $+1 \%$ Sericin and 2\% Sodium Alginate $+0.5 \%$ Sericin $+0.5 \%$ Phyboplus, respectively (Fig. 1).

Encapsulation of probiotic cells in the combination with prebiotics increased cell survival due to encapsulation techniques performed in mild conditions [14]. No significant difference $(p \geq 0.05)$ in diameter of encapsulated microgel was achieved. The size of gel beads was in the range of 2.320-2.403 mm (Table 1). Chandramoulia et al. [15] suggested that probiotic survival increased with gel bead size. Moreover, Mortazavian, et al. [16] revealed a correlation between size of microcapsule and solution viscosity. A higher solution viscosity resulted in a larger size of microcapsule particles. Large microcapsule particles resulted in longer exposure to the unsuitable environment than the smaller particles obtained by the use of low concentrations of encapsulation agents.

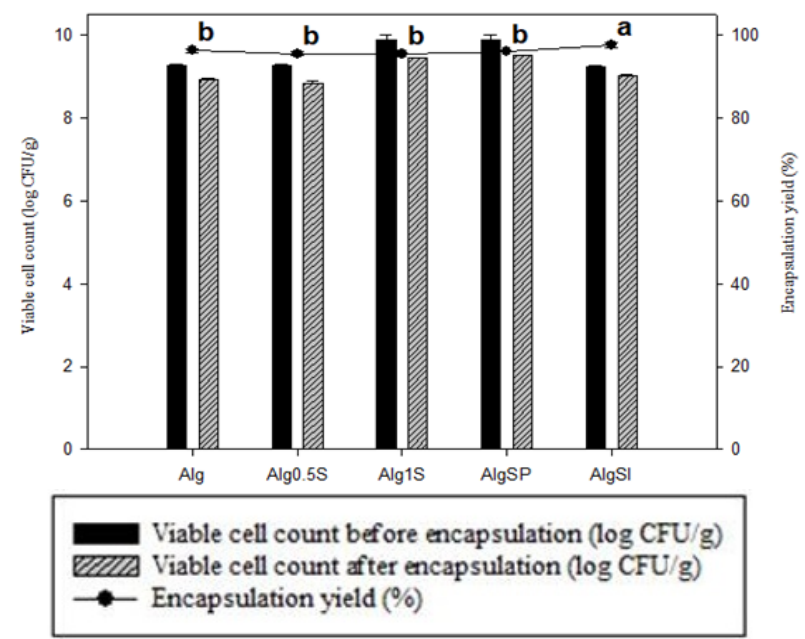

Fig. 1. Encapsulation efficiency of probiotic with various wall materials. The values of encapsulation efficiency expressed with different lowercase letters are significant differences $(\mathrm{p}<0.05) . \mathrm{Alg}=2 \%$ Sodium Alginate, $\mathrm{Alg} 0.5 \mathrm{~S}=2 \%$ Sodium Alginate $+0.5 \%$ Sericin, Alg $1 \mathrm{~S}=2 \%$ Sodium Alginate $+1 \%$ Sericin, AlgSP $=2 \%$ Sodium Alginate $+0.5 \%$ Sericin $+0.5 \%$ Phyboplus, AlgSI $=2 \%$ Sodium Alginate $+0.5 \%$ Sericin + $0.5 \%$ Isomalt.

Table 1 The particle size of microcapsules with different wall materials. ns showed no significant difference $(\mathrm{p} \geq 0.05)$.

\begin{tabular}{lc}
\multicolumn{1}{c}{ Wall materials } & Size $) \mathrm{mm} .(\mathrm{ns}$ \\
\hline $2 \%$ Alginate & $2.403 \pm 0.13$ \\
\hline $2 \%$ Alginate $+0.5 \%$ Sericin & $2.320 \pm 0.14$ \\
\hline $2 \%$ Alginate $+1 \%$ Sericin & $2.363 \pm 0.10$ \\
\hline $\begin{array}{l}\text { 2\% Alginate }+0.5 \% \text { Sericin }+ \\
0.5 \% \text { Phyboplus }\end{array}$ & $2.357 \pm 0.13$ \\
\hline $2 \%$ Alginate $+0.5 \%$ Sericin $+0.5 \%$ Isomalt & $2.372 \pm 0.15$ \\
\hline
\end{tabular}

\subsection{The survival rate of encapsulated cells with various prebiotics after freeze-drying}

The survival rate of encapsulated probiotic strain was performed after freeze drying. The survival of encapsulated microparticles with alginate, sericin and different prebiotics and subjected to freeze-drying process were statistically differences $(\mathrm{p}<0.05)$. The survival rate of encapsulated probiotic with $2 \%$ Sodium alginate $+0.5 \%$ Sericin $+0.5 \%$ Isomalt had the highest survival rate of $99.78 \%$ (Fig. 2). Adding protective agent appears to enhance cell viability of probiotic. The ability of prebiotics to protect probiotic cells is related to its ability to replace water during dehydration [17].

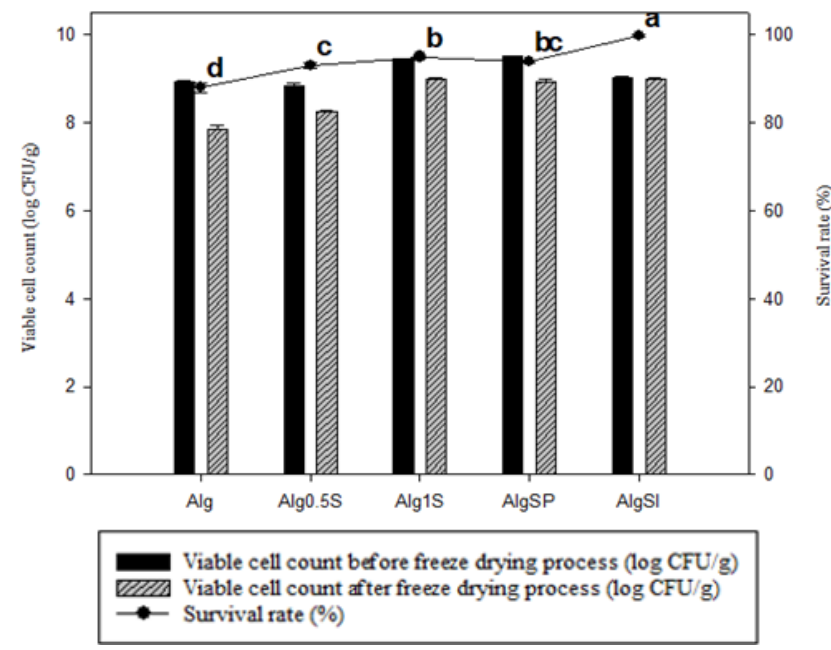

Fig. 2. The survival rates of encapsulated probiotic with different prebiotics after freeze drying process. The values of survival rate expressed with different lowercase letters are significant differences $(\mathrm{p}<0.05)$. Alg $=$ $2 \%$ Sodium Alginate, Alg $0.5 \mathrm{~S}=2 \%$ Sodium Alginate $+0.5 \%$ Sericin, Alg1S $=2 \%$ Sodium Alginate $+1 \%$ Sericin, AlgSP $=2 \%$ Sodium Alginate $+0.5 \%$ Sericin $+0.5 \%$ Phyboplus, AlgSI $=2 \%$ Sodium Alginate $\quad+0.5 \%$ Sericin $+0.5 \%$ Isomalt.

\subsection{The stability of freeze-dried encapsulated probiotic during storage}

Specific rate of degradation $(k)$ was investigated in the correlation of microorganism reduction rate over the storage time. Through the encapsulating cells with different wall materials, lower storage temperature at $4^{\circ} \mathrm{C}$ resulted in higher survival rate with lower $k$ value and the co-encapsulation with prebiotics exhibited a great storage stability.

Encapsulated probiotic with 2\% Sodium Alginate $+0.5 \%$ Sericin $+0.5 \%$ Phyboplus demonstrated the lowest $k$ value of $3.74 \times 10^{-2}$ day $^{-1}$ and $1.09 \times 10^{-1}$ day $^{-1}$ at $4^{\circ} \mathrm{C}$ and $30^{\circ} \mathrm{C}$, respectively (Table 2). The temperature of $4^{\circ} \mathrm{C}$ provided higher probiotic survival than at $30^{\circ} \mathrm{C}$ storage. This results suggested that co-encapsulation of alginate, sericin and prebiotic constitutes an alternative for maintaining probiotic viability during storage in refrigeration for up to 90 days. 
Table 2 Viability of dried encapsulated probiotic kept at $4{ }^{\circ} \mathrm{C}$ and $30^{\circ} \mathrm{C}$

\begin{tabular}{lcc}
\hline \multicolumn{1}{c}{ Protectants } & $\begin{array}{c}\text { Storage } \\
\text { temperature } \\
4{ }^{\circ} \mathrm{C}\end{array}$ & $\begin{array}{c}\text { Storage } \\
\text { temperature } \\
30^{\circ} \mathrm{C}\end{array}$ \\
\cline { 2 - 3 } & $k_{4{ }^{\circ} \mathrm{C}\left(\mathrm{day}^{-1}\right)}$ & $k_{30^{\circ} \mathrm{C}\left(\mathrm{day}^{-1}\right)}$ \\
\hline $2 \%$ Alginate & $5.27 \times 10^{-2}$ & $2.27 \times 10^{-1}$ \\
\hline $\begin{array}{l}2 \% \text { Alginate }+ \\
0.5 \% \text { sericin }\end{array}$ & $4.10 \times 10^{-2}$ & $2.19 \times 10^{-1}$ \\
\hline $\begin{array}{l}2 \% \text { Alginate }+ \\
1 \% \text { sericin }\end{array}$ & $4.91 \times 10^{-2}$ & $4.62 \times 10^{-1}$ \\
\hline $\begin{array}{l}2 \% \text { Alginate }+0.5 \% \\
\text { sericin }+ \text { phyboplus }\end{array}$ & $3.74 \times 10^{-2}$ & $1.09 \times 10^{-1}$ \\
\hline $\begin{array}{l}2 \% \text { Alginate }+ \\
0.5 \% \text { sericin }+ \text { isomalt }\end{array}$ & $4.88 \times 10^{-2}$ & $1.61 \times 10^{-1}$ \\
\hline
\end{tabular}

\subsection{Microstructure of capsules}

Characterization of encapsulated probiotic gel beads with alginate, sericin extract and different prebiotics were carried out by stereo microscope and Scanning Electron Microscope (SEM) were obtained as shown in (Figure 3). The morphology of encapsulated cells after freeze-drying by stereo microscope showed that the gel beads contracted and formed a porous appearance, resulting in non-spherical shape. The constricted and porous structure of encapsulated microbeads resulted from the water loss during dehydration [18]. The morphology of encapsulated cells after freeze-drying by SEM showed that the probiotic cells were homogeneous with the protective agents on the surface

\subsection{Cell surface hydrophobicity of encapsulated probiotic}

The hydrophobic properties of encapsulated probiotic after freeze drying were determined. Encapsulated probiotic with $2 \%$ sodium alginate had the highest cell surface hydrophobicity value of $71.65 \%$, while $2 \%$ Sodium Alginate $+0.5 \%$ Sericin $+0.5 \%$ Phyboplus has the lowest adhesion value of $21.16 \%$ (Table 3). The hydrophobicity of probiotic cells is associated with their ability to bind in the gut, which is considered a property of probiotics. Hydrophobia related with the amount of surface protein in probiotic strain Lactobacillus. Different levels of hydrophobic cells resulted in different adhesion variations [19]. The encapsulated probiotic with only $2 \%$ sodium alginate demonstrated the highest cell surface hydrophobic which link to the adhesion to the epithelial wall which is considered a hallmark of being a probiotic.

\section{Conclusion}

In conclusion, the encapsulation of probiotic $L$. casei TISTR 1463 with $2 \%$ sodium alginate $+0.5 \%$ sericin $+0.5 \%$ Isomalt exhibited the highest level of encapsulation efficiency and survival rate after freeze drying compared with other conditions. Encapsulated probiotic by sericin combined with different prebiotics promoted survival rate better than free cells. While, $2 \%$ sodium alginate $+0.5 \%$ sericin $+0.5 \%$ phyboplus showed the highest storage stability related to the lowest $k$ values at $4^{\circ} \mathrm{C}$ and $30^{\circ} \mathrm{C}$. This research could be used to develop new functions to increase the protection of probiotics to be more effective in the future.

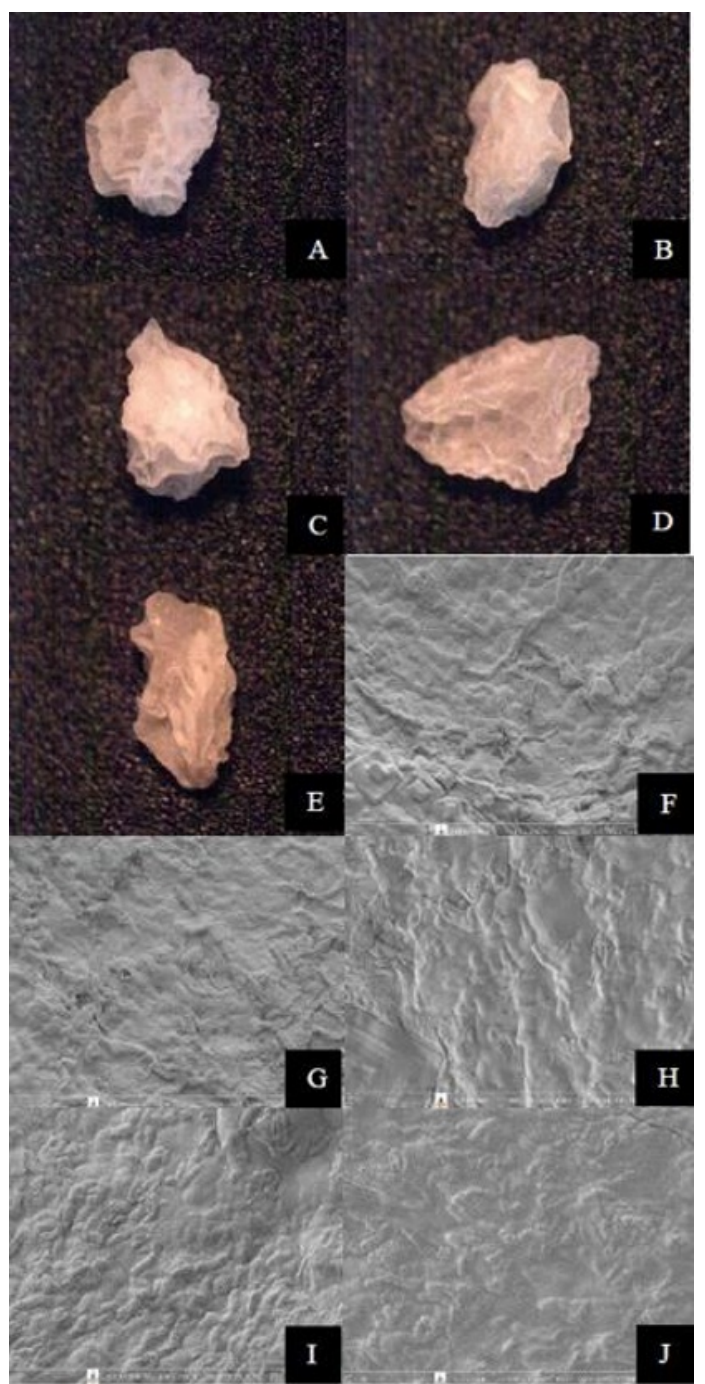

Fig.3 Stereo microscope images (A-E) and scanning electron micrographs images (F-J) of freeze-dried encapsulated probiotic with various wall materials. $\mathrm{A}, \mathrm{F}=2 \%$ Sodium Alginate, $\mathrm{B}, \mathrm{G}=2 \%$ Sodium Alginate $+0.5 \%$ Sericin, $\mathrm{C}, \mathrm{H}=$ $2 \%$ Sodium Alginate $+1 \%$ Sericin, $\mathrm{D}, \mathrm{I}=2 \%$ Sodium Alginate $+0.5 \%$ Sericin $+0.5 \%$ Phyboplus, E,J $=2 \%$ Sodium Alginate $+0.5 \%$ Sericin $+0.5 \%$ Isomalt.

Table 3 Cell surface hydrophobicity probiotics with different prebiotics

\begin{tabular}{lc}
\hline \multicolumn{1}{c}{ Wall materials } & $\begin{array}{c}\text { Cell surface } \\
\text { hydrophobicity }(\%) \pm \mathrm{SD}\end{array}$ \\
\hline $2 \%$ Sodium Alginate & $71.65 \pm 1.81^{\mathrm{a}}$ \\
\hline $\begin{array}{l}2 \% \text { Sodium Alginate }+ \\
0.5 \% \text { Sericin }\end{array}$ & $54.07 \pm 4.26^{\mathrm{bc}}$ \\
\hline $\begin{array}{l}\text { 2\% Sodium Alginate }+ \\
1 \% \text { Sericin }\end{array}$ & $44.41 \pm 4.69^{\mathrm{c}}$ \\
\hline $\begin{array}{l}2 \% \text { Sodium Alginate }+ \\
0.5 \% \text { Sericin }+0.5 \%\end{array}$ & $21.16 \pm 2.89^{\mathrm{d}}$ \\
Phyboplus & $47.71 \pm 4.09^{\mathrm{bc}}$ \\
\hline $\begin{array}{l}2 \% \text { Sodium Alginate }+ \\
0.5 \% \text { Sericin }+0.5 \% \text { Isomalt }\end{array}$ & \\
\hline
\end{tabular}

The values of cell surface hydrophobicity expressed with different lowercase letters are significant differences by DMRT $(\mathrm{p}<0.05)$ 


\section{Acknowledgement}

I would like to extend my thanks to my scholarship provider, the Agricultural Research Development Agency (ARDA), Thailand, who gave me an unforgettable opportunity to come to explore the scientific world at the King Mongkut's University of Technology North Bangkok to fulfil my master degree study.

\section{References}

1. K. Kailasapathy, Encapsulation technologies for functional foods and nutraceutical product development, CAB Reviews: Perspectives in Agriculture, (2009).

2. R. Fuller, Probiotics in man and animals, Journal of Applied Microbiology, 66 (1989): 365-378

3. P. De Vos, M.M. Faas, M. Spasojevic, J. Sikkema, Encapsulation for preservation of functionality and targeted delivery of bioactive food components, International Dairy Journal, 20 (2010): 292-302,

4. M.J. Chen, K.N. Chen, Applications of probiotic encapsulation in dairy products, In: Lakkis, M. Jamileh, Encapsulation and Controlled Release Technologies in Food Systems, Wiley-Blackwell USA, (2007): 83-107

5. M. Borgogna, B. Bellich, L. Zorzin, R. Lapasin, A. Cesàro, Food microencapsulation of bioactive compounds: rheological and thermal characterisation of non-conventional gelling system, Food Chemistry, 122 (2010): 416-423

6. M.T. Cook, G. Tzortzis, D. Charalampopulos, V.V. Khutoryanskiy, Microencapsulation of probiotics for gastrointestinal delivery, Journal of Controlled Release, 162 (2012): 56-67

7. M.D. Piano, S. Carmagnola, S. Andorno, M. Pagliarulo, R. Tari, L. Mogna, L. Capurso, Evaluation of the intestinal colonization by microencapsulated probiotic bacteria in comparison with the same uncoated strains, Journal of Clinical Gastroenterology, 44, (2010): 42-46

8. A. Sipailiene, S. Petraityte, Encapsulation of probiotics: Proper selection of the probiotic strain and the influence of encapsulation technology and materials on the viability of encapsulated microorganisms, Probiotics and Antimicrobial Probiotic, 10 (2018): 1-10,
9. L.K. Sarao, M. Arora, Probiotics, prebiotics, and microencapsulation: A review. Critical Reviews in Food Science and Nutrition, 57 (2017): 344-371

10. L. Lallepak, G. Mario, Y. Guang, W. Qun, Silk sericin: A versatile material for tissue engineering and drug delivery, Biotechnology Advances, 33 (2015): 1855-1867

11. S.B. Doherty, V.L. Gee, R.P. Ross, C. Stanton, G.F. Fitzgerald, A. Brodkorb, Development and characterisation of whey protein micro-beads as potential matrices for probiotic protection, Food Hydrocolloids, 25 (2011): 1604-1617

12. W. Savedboworn, K. Teawsomboonkit, S. Surichay, W. Riansa-ngawong, S. Rittisak, R. Charoen, Impact of protectants on the storage stability of freeze-dried probiotic Lactobacillus plantarum, Food Science and Biotechnology, 28 (2019): 795805

13. W. Savedboworn, W. Riansa-ngawong, W. Sinlapacharoen, S. Pajakang, B. Patcharajarukit, Assessment of Probiotic Properties in Lactic Acid Bacteria Isolated from Fermented Vegetables, Applied Science and Engineering Progress, 7 (2014) : 53-65

14. W. Krasaekoopt, B. Bhandari, H. Deeth, Evaluation of encapsulation techniques of probiotic for youhurt, International Dairy Journal, 13 (2003): 3-13

15. V. Chandramoulia, K. Kailasapathya, P. Peirisb, M. Jones, An improved method of microencapsulation and its evaluation to protect Lactobacillus spp. In simulated gastric conditions, The Journal of Microbiological Methods, 56 (2004): 27-35

16. A. Mortazavian, S.H. Razavi, M.R. Ehsani, S. Sohrabvandi, Principles and of microencapsulation of probiotic microorganisms, Iranian Journal of Biotechnology, 5 (2007): 1-18

17. J.H. Crowe, J.F. Carpenter, L.M. Crowe, The role of vitrification in anhy-drobiosis. Annual Review of Physiology, 60 (1998): 73-103

18. S. Ambros, A.H. Vollmer, N.N. Youssef, U. Kulozik, Structural basis of the impact of microwave drying on survival and shelf life of Lactobacillus paracasei, Lebensmittel-Wissenschaft \& Technologie, 98 (2018): 291-298

19. T.P. Singh, R.K. Malik, G. Kaur, Cell surface proteins play an important role in probiotic activities of Lactobacillus reuteri. Nutrire, 41 (2016): 1-10 